\title{
HUBUNGAN ANTARA TEKSTUR SEDIMEN, KANDUNGAN BAHAN ORGANIK DAN KELIMPAHAN MAKROZOOBENTHOS DI PERAIRAN MUARA BANJIR KANAL BARAT, SEMARANG
}

\author{
Relationship Between Sediment Texture, Organic Matters and Macrozoobenthos Abundance in West Banjir Kanal \\ Estuary, Semarang
}

\section{Rizka Ummi Arofah, Max Rudolf Muskananfola*), Oktavianto Eko Jati}

Program Studi Manajemen Sumberdaya Perairan, Departemen Sumberdaya Akuatik

Fakultas Perikanan dan Ilmu Kelautan, Universitas Diponegoro

Jl. Prof. Suedarto, SH, Tembalang, Semarang, Jawa Tengah - 50275, Telp/Fax. +6224 7474698

Email : rizkaummi.rua@gmail.com

\begin{abstract}
ABSTRAK
Sungai Banjir Kanal Barat Semarang merupakan sungai dengan daerah padat pemukiman yang menyumbang suplai material organik maupun anorganik. Hal ini dapat menyebabkan pencemaran di perairan tersebut. Limbah dapat mempengaruhi kualitas perairan dan biota di dalamnya. Tujuan dari penelitian adalah untuk mengetahui hubungan antara kandungan bahan organik sedimen dengan kelimpahan makrozoobenthos, hubungan antara tekstur sedimen dengan kandungan bahan organik sedimen, serta hubungan antara tekstur sedimen dengan kelimpahan makrozoobenthos di muara dan sungai Banjir Kanal Barat, Semarang. Penelitian ini dilaksanakan pada bulan Maret April 2018 dengan menggunakan metode kuantitatif. Penentuan lokasi sampling menggunakan purposive sampling yang terdiri dari 4 stasiun. Metode analisis statistik yang digunakan adalah uji normalitas, korelasi, regresi. Makrozoobenthos yang didapatkan adalah Nereis, Nephthys, Melanoides, Cerithium, Pomacea, Dreissena, dan Corbicula. Fraksi liat dan kandungan bahan organik memiliki hubungan yang positif dengan nilai korelasi $\mathrm{r}=0,893$. Fraksi liat dengan kelimpahan makrozoobenthos memiliki hubungan yang positif dengan nilai korelasi $r=0,906$. Hal ini sama dengan kandungan bahan organik sedimen dengan kelimpahan makrozoobenthos juga memiliki hubungan yang positif dengan nilai korelasi $\mathrm{r}=0,928$. Semakin besar kandungan bahan organik sedimen dan makrozoobenthos. Kualitas perairan berdasarkan indeks keanekaragaman di stasiun IV sebesar 1,2 yang tergolong tercemar sedang. Sedangkan pada stasiun I, II dan III dengan nilai 0,$15 ; 0,15 ; 0,93$ termasuk tercemar berat.
\end{abstract}

Kata kunci: Bahan organik sedimen, Makrozoobenthos, Tekstur sedimen.

\begin{abstract}
Banjir Kanal Barat Semarang is a river with densely populated areas that contribute to the supply of organic and inorganic materials. This can cause pollution in these waters. Waste can affect the quality of water and biota in it. The purpose of this study was to determine the relationship between sediment organic matter with abundance of macrozoobenthos, the relationship between sedimentary texture and organic sediment materials, as well as the relationship between sedimentary texture and abundance of macrozoobenthos in estuaries of Banjir Kanal Barat, Semarang. This research was conducted in March - April 2018 using kuantitative method. Kinds of macrozoobenthos was found from genus Nereis, Nephthys, Melanoides, Cerithium, Pomacea, Dreissena, and Corbicula. Determination of the sampling location using purposive sampling method. The clay fraction and the abundance of sediment organic matter have a positive relationship with the correlation value $r=0.893$. The clay fraction with abundance of macrozoobenthos has a positive relationship with the correlation value $r=0.906$. This is the same as the abundance of organic sediment material with abundance of macrozoobenthos also has a positive relationship with the correlation value $r=0.928$. the greater the percentage of clay, the more abundant the organic matter of sediment and makrozoobenthos.
\end{abstract}

Keyword : Sediment Organic Matter; Macrozoobenthos; Sediment Texture.

*) Penulis Penanggungjawab

\section{PENDAHULUAN}

Sungai Banjir Kanal Barat merupakan salah satu sungai besar yang mengalir di daerah Semarang. Sungai yang melintas di kota besar dan pemukiman penduduk serta daerah industri mengalami penurunan kualitas air. Hal tersebut disebabkan karena sebagian besar limbah cair domestik yang dihasilkan oleh pemukiman penduduk mengalir ke perairan sungai. Secara tidak langsung sungai dan muara terkena dampak negatif dari kegiatan manusia yang menyebabkan pencemaran air terutama penambahan bahan organik secara berlebih. Menurut Hadiputra dan Damayanti 
(2013), bahan pencemar dapat mengganggu dan membahayakan organisme air yang hidup didalamnya, salah satunya adalah makrozoobenthos.

Tujuan dari penelitian ini adalah untuk mengetahui hubungan antara kandungan bahan organik sedimen dengan kelimpahan makrozoobenthos, hubungan antara tekstur sedimen dengan kandungan bahan organik sedimen, hubungan antara tekstur sedimen dengan kelimpahan makrozoobenthos, struktur komunitas makrozoobenthos, serta tingkat pencemaran berdasarkan indeks keanekaragaman makrozoobenthos yang diperoleh di muara Banjir Kanal Barat, Semarang. Penelitian ini dilaksanakan pada bulan Maret - April 2018 dengan menggunakan metode deskriptif. Penentuan lokasi sampling menggunakan purposive sampling. Hasil dari penilitian ini diharapkan dapat memberikan informasi mengenai kondisi perairan Sungai dan Muara Banjir Kanal Barat, Semarang.

\section{MATERI DAN METODE PENELITIAN}

\section{a. Materi Penelitian}

Materi yang digunakan dalam penelitian ini adalah substrat dasar (sedimen) dan makrozoobenthos serta pengamatan kualitas air yang meliputi parameter fisika dan kimia seperti salinitas, $\mathrm{pH}$, suhu perairan dan kecepatan arus yang diambil di lokasi penelitian di Sungai dan Muara Banjir Kanal Barat, Semarang.

\section{b. Metode Penelitian}

Metode yang digunakan dalam penelitian ini adalah metode kuantitatif, merupakan penelitian menggunakan analisis data yang berbentuk numerik/angka. Tujuan penelitian kuantitatif yaitu untuk mengembangkan dan menggunakan model matematis, teori dan atau hipotesis yang berkaitan dengan fenomena yang diselidiki. (Suryani dan Hendryadi, 2015)

\section{Penentuan Lokasi dan Pengambilan Sampel}

Penentuan lokasi dilakukan setelah melakukan pengamatan langsung dilapangan. Penentuan lokasi sampling berdasarkan kebutuhan dan dapat mewakili wilayah penelitian secara keseluruhan. Pengambilan sampel menggunakan metode purposive sampling, dimana teknik pengambilan sampel masing - masing stasiun dapat mewakili wilayah penelitian secara keseluruhan sehingga memperkecil terjadinya bias terhadap data yang diperoleh. Penentuan lokasi berdasarkan limbah yang dihasilkan. Stasiun I dan II merupakan lokasi dengan pasokan limbah industri dan pemukiman, serta terdapat pintu air masuknya limbah domestik, terdapat pertambakan dan vegetasi bakau. Stasiun III dan IV dilokasi mulut sungai dan muara, untuk melihat dampak yang diakibatkan dari limbah. Lokasi sampling ke empat stasiun disajikan pada Gambar 1.

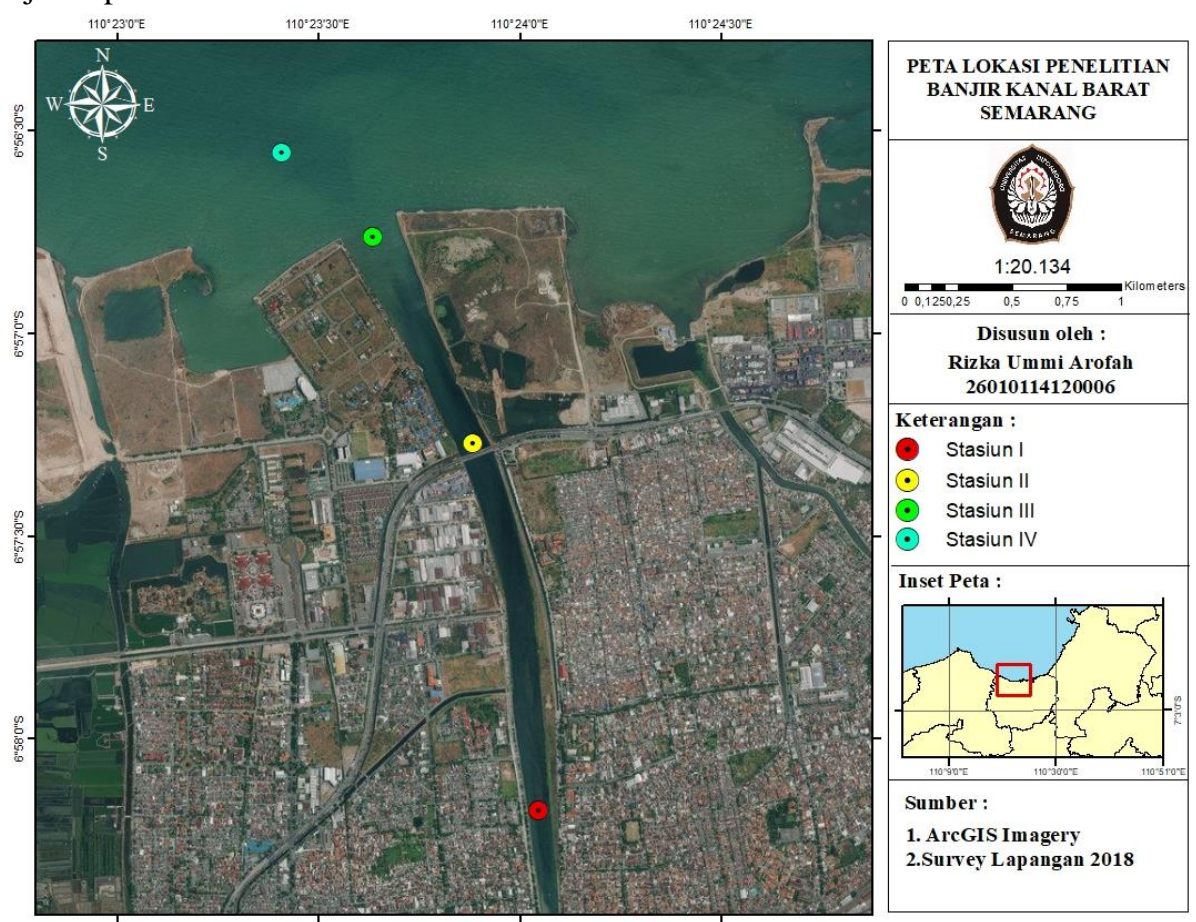

Gambar 1. Lokasi Penelitian

Pengambilan sampel berupa sedimen dan makrozoobenthos dengan mengambil substrat dasar perairan menggunakan Van veen grab. Dalam penelitian ini ditentukan 4 stasiun pengukuran, dimana pada tiap stasiun dilakukan 3 kali pengulangan pada interval waktu 2 minggu sekali. Pengambilan sampel pada 4 stasiun yang berbeda yaitu stasiun 
I terletak pada perairan sungai dengan inlet pembuangan limbah industri dan pemukiman, stasiun II terletak pada perairan sungai dekat dengan tambak dan pohon bakau, stasiun III terletak pada perairan muara yang berbatasan dengan laut. stasiun IV terletak di perairan muara yang dekat dengan laut. Sampel biota disaring untuk memisahkannya dari kotoran. Sampel dimasukkan dalam kantong plastik kemudian ditetesi formalin $4 \%$. Setelah itu biota diidentifikasi dengan menggunakan mikroskop. Sampel substrat dasar (sedimen) yang didapat kemudian di lakukan pengujian tekstur tanah dengan menggunakan metode pengayakan dan pemipetan berdasarkan Buchanan (1971) dan memisahkan tekstur menjadi tiga fraksi yaitu Sand, Silt, dan Clay. Bahan organik sedimen dianalisis dengan menggunakan metode gravimetri. Metode ini semua bahan organic dianggap menguap bila dibakar pada suhu $550^{\circ} \mathrm{C}$ selama 4 jam.

\section{Identifikasi Makrozoobenthos}

Sampel makrozoobenthos yang telah diperoleh selanjutnya diidentifikasi dengan menggunakan mikroskop binokuler. Proses identifikasi dilakukan dengan mengamati ciri-ciri morfologi, dengan mengacu pada buku petunjuk identifikasi makrozoobenthos.

\section{Analisa Struktur Komunitas Makrozoobenthos}

a. Kelimpahan Jenis

Kelimpahan jenis dihitung berdasarkan jumlah individu per satuan luas (ind $\left./ \mathrm{m}^{2}\right)$.

b. kelimpahan relative

Untuk mengetahui kelimpahan dan kelimpahan relative digunakan formula menurut Krebs (1985) dalam Choirudin et al., (2014) sebagai berikut :

$$
\mathrm{K}=\frac{\mathrm{ni}}{\mathrm{N}} \times 100 \%
$$

Keterangan:

$\mathrm{KR}=$ kelimpahan relative

$\mathrm{ni}=$ jumlah kelimpahan individu spesies

$\mathrm{N}=$ jumlah total kelimpahan seluruh spesies

c. Indeks keanekaragaman jenis $\left(\mathrm{H}^{\prime}\right)$

Menurut Ridwan et al,. (2016), Indeks keanekaragaman jenis dan merupakan suatu ciri khas komunitas.

Keanekaragaman ditentukan berdasarkan indeks keaneragaman Shannon-Wiener dengan rumus sebagai berikut:

$$
\mathrm{H}^{\prime}=-\sum_{\mathrm{i}=1}^{\mathrm{s}}(\mathrm{pi})(\ln \mathrm{pi})
$$

Keterangan :

$\mathrm{Pi}=$ Jumlah individu masing-masing jenis $(\mathrm{i}=1,2,3, \ldots, \mathrm{dst})$

$\mathrm{S}=$ Jumlah jenis

$\mathrm{H}^{\prime}=$ Penduga keragaman populasi

Kriteria Indeks Keanekaragaman Jenis Makrozoobenthos

\begin{tabular}{cc}
\hline Kriteria & Indeks keanekaragaman jenis \\
\hline Tinggi & $>2,0$ \\
Sedang & $\leq 2,0$ \\
Rendah & $<1,6$ \\
Sangat rendah & $<1,0$ \\
\hline
\end{tabular}

d. Indeks Keseragaman (e)

Menurut Noortiningsih et al.,(2008), indeks keseragaman diperoleh dengan cara sebagai berikut:

$$
\mathrm{e}=\frac{H^{\prime}}{\ln s}
$$

Keterangan :

e $\quad$ : indeks keseragaman (Evenness index)

H' : indeks keanekaragaman Shannon-Wiener

s : jumlah genus 
e. $\quad$ Indeks Dominasi (C) berikut:

Menurut Odum (1971) dalam Fitriana (2006), indeks dominasi didapat dengan menggunakan rumus sebagai

$$
\mathrm{C}=\sum \mathrm{Pi}^{2}=\sum \sum\left(\mathrm{n}_{\mathrm{i}} / \mathrm{N}\right)^{2}
$$

Keterangan

C : indeks dominansi (Index of dominance)

$\mathrm{n}_{\mathrm{i}} \quad$ : nilai dari setiap genus (jumlah jenis individu ke-i)

$\mathrm{N} \quad$ : nilai total dari seluruh genus (jumlah individu total yang telah ditemukan)

$\mathrm{P}_{\mathrm{i}} \quad$ : perbandingan jumlah individu jenis ke-i dengan jumlah individu total yang telah ditemukan.

\section{HASIL DAN PEMBAHASAN}

a. Tekstur Sedimen

Hasil analisis tekstur sedimen yang diperoleh berupa nilai komposisi pasir dan liat. Stasiun I didominasi oleh pasir dengan persentase $83,40 \%$. Stasiun II didominasi oleh liat sebesar 67,35\%. Sedangkan di mulut sungai dan muara didominasi oleh liat. Semakin menuju ke laut, persentase liat semakin besar. Hasil analisis tekstur sedimen tersaji pada Tabel 1.

Tabel 1. Hasil Analisis Tekstur Sedimen dan Komposisinya.

\begin{tabular}{|c|c|c|c|c|c|}
\hline \multirow[t]{2}{*}{ Stasiun } & \multirow{2}{*}{ Ulangan } & \multicolumn{3}{|c|}{ Persentase $(\%)$} & \multirow[t]{2}{*}{ Jenis tekstur } \\
\hline & & Sand & Silt & Clay & \\
\hline \multirow[t]{3}{*}{$\mathrm{I}$} & 1 & 76,57 & 0,05 & 23,38 & \\
\hline & 2 & 84,39 & 0,09 & 15,52 & \\
\hline & 3 & 89,24 & 0,04 & 10,72 & Lempung \\
\hline Rata-rata & & 83,40 & 0,06 & 16,54 & Berpasir \\
\hline \multirow[t]{3}{*}{ II } & 1 & 27,60 & 0,02 & 72,38 & \\
\hline & 2 & 29,31 & 0,28 & 70,41 & Lempung \\
\hline & 3 & 40,05 & 0,69 & 59,26 & liat \\
\hline Rata-rata & & 32,32 & 0,33 & 67,35 & Berpasir \\
\hline \multirow[t]{3}{*}{ III } & 1 & 25,45 & 0,31 & 74,24 & \\
\hline & 2 & 28,82 & 0,29 & 70,89 & \\
\hline & 3 & 40,17 & 0,45 & 59,38 & \\
\hline Rata-rata & & 31,48 & 0,35 & 68,17 & Liat \\
\hline \multirow[t]{3}{*}{ IV } & 1 & 26,63 & 0,35 & 73,02 & \\
\hline & 2 & 12,07 & 0,23 & 87,70 & \\
\hline & 3 & 10,50 & 0,56 & 88,94 & \\
\hline Rata-rata & & 16,40 & 0,38 & 83,22 & Liat \\
\hline
\end{tabular}

\section{b. Bahan Organik Sedimen}

Berdasarkan hasil yang diperoleh dari analisis bahan organik sedimen pada Tabel 8 dan Gambar 4. persentase tertinggi didapatkan di stasiun II pengulangan 1, dengan rata-rata sebesar 12,78 \%. Persentase tersebut menunjukkan bahwa di stasiun II memiliki kandungan bahan organik sedimen tergolong sedang. Sedangkan persentase terendah didapatkan di stasiun I pengulangan 2 yaitu sebesar 5,53\% yaitu tergolong rendah. Hasil analisis bahan organik tersaji pada Tabel 2 .

Tabel 2. Kelimpahan Bahan Organik Sedimen

\begin{tabular}{cccccc}
\hline \multirow{2}{*}{ Stasiun } & \multirow{2}{*}{ Ulangan } & \multicolumn{3}{c}{ Persentasi per titik (\%) } & \multirow{2}{*}{ Rata-rata (\%) } \\
\cline { 3 - 5 } & & $\mathbf{1}$ & $\mathbf{2}$ & $\mathbf{3}$ & 7,45 \\
I & 1 & 8,36 & 8,42 & 5,56 & 5,53 \\
& 2 & 5,47 & 5,05 & 6,08 & 6,23 \\
\hline II & 1 & 5,86 & 7,06 & 5,77 & 12,78 \\
& 2 & 12,04 & 6,24 & 20,75 & 10,8 \\
& 3 & 10,82 & 8,01 & 13,57 & 11,55 \\
\hline
\end{tabular}




\begin{tabular}{cccccc}
\hline III & 1 & 9,05 & 12,43 & 8,23 & 9,90 \\
& 2 & 10,82 & 11,47 & 9,87 & 10,72 \\
& 3 & 6,34 & 6,91 & 9,06 & 7,44 \\
\hline IV & 1 & 10,45 & 12,26 & 11,77 & 11,39 \\
& 2 & 8,23 & 7,84 & 10,17 & 8,75 \\
& 3 & 6,88 & 9,28 & 7,86 & 8,00 \\
\hline
\end{tabular}

\section{c. Makrozoobenthos}

Hasil kelimpahan individu dan kelimpahan relatif makrozoobenthos di Muara Banjir Kanal Barat, Semarang didapatkan kelimpahan individu tertinggi di stasiun II, yaitu sebesar $462 \mathrm{ind} / \mathrm{m}^{2}$. Hal ini dikarenakan genus melanoides mendominasi wilayah tersebut sebesar $119 \mathrm{ind} / \mathrm{m}^{2}$. Sedangkan kelimpahan total individu terendah terdapat di stasiun I, yaitu sebesar $123 \mathrm{ind} / \mathrm{m}^{2}$. Kelimpahan individu dan kelimpahan relatif dapat dilihat pada Tabel 3.

Tabel 3. Kelimpahan Individu dan Kelimpahan Relatif Makrozoobenthos.

\begin{tabular}{|c|c|c|c|c|c|c|c|c|c|}
\hline \multirow{3}{*}{ Genus } & \multicolumn{8}{|c|}{ Stasiun } & \multirow{4}{*}{$\begin{array}{l}\text { Hubung } \\
\text { an } \\
\text { antara }\end{array}$} \\
\hline & \multicolumn{2}{|c|}{1} & \multicolumn{2}{|c|}{2} & \multicolumn{2}{|c|}{3} & \multicolumn{2}{|c|}{4} & \\
\hline & KI & KR & KI & KR & KI & KR & $\mathrm{KI}$ & KR & \\
\hline Polychaeta & & & & & & & & & \\
\hline Nereis & 0 & 0 & 0 & 0 & 0 & 0 & 26 & 12,2 & $\begin{array}{l}\text { antara } \\
\text { kanduno }\end{array}$ \\
\hline Nepthys & 0 & 0 & 9 & 1,88 & 4 & 1,5 & 22 & 10,2 & \\
\hline Gastropoda & & & & & & & & & bahan \\
\hline Melanoides & 119 & 96,5 & 449 & 97,1 & 207 & 68,1 & 0 & 0 & organik \\
\hline Cerithium & 0 & 0 & 0 & 0 & 53 & 17,3 & 101 & 47 & sedimen \\
\hline Pomacea & 0 & 0 & 0 & 0 & 4 & 1,5 & 0 & 0 & kelimpa \\
\hline Bivalve & & & & & & & & & han \\
\hline Dreissena & 0 & 0 & 4 & 0,9 & 35 & 11,6 & 66 & 30,6 & makrozo \\
\hline Corbicula & 4 & 3,5 & 0 & 0 & 0 & 0 & 0 & 0 & obenthos \\
\hline Jumlah & 123 & 100 & 462 & 100 & 303 & 100 & 468 & 100 & Berdasar \\
\hline
\end{tabular}

kan hasil uji korelasi regresi antara kelimpahan individu (KI) dengan kandungan bahan organik sedimen diperoleh nilai koefesien korelasi sebesar 0,928. Hasil tersebut menyatakan bahwa terdapat hubungan yang kuat antara kandungan bahan organik dan kelimpahan makrozoobenthos di muara Banjir Kanal Barat, Semarang. Nilai $\mathrm{R}^{2}$ menunjukkan bahwa sebesar 86,2\% kelimpahan bahan organik sedimen mempengaruhi kelimpahan makrozoobenthos, sedangkan $13,8 \%$ dipengaruhi oleh faktor lain. Nilai koefesien korelasi (r) sebesar 0,928. Nilai ini menunjukkan bahwa hubungan antara kedua variabel kuat.Hubungan tersebut dibuktikan oleh nilai significance F sebesar 0,00. Nilai Sig. F lebih kecil dari 0,05. Hal ini menunjukkan adanya pengaruh positif nyata antara kandungan bahan organik sedimen dengan kelimpahan makrozoobenthos. Hal ini diperkuat oleh Nurrahmi dan Marwan (2012) dalam Mushthofa et al., (2014), yang menyatakan bahwa hewan bethos erat kaitannya dengan ketersediaan bahan organik yang terkandung dalam substrat, karena bahan organik merupakan sumber nutrien bagi biota yang pada umumnya terdapat pada substrat dasar.Berikut ini disajikan grafik uji regresi linear antara kelimpahan makrozoobenthos dengan kandungan bahan organik sedimen pada Gambar 2 . 


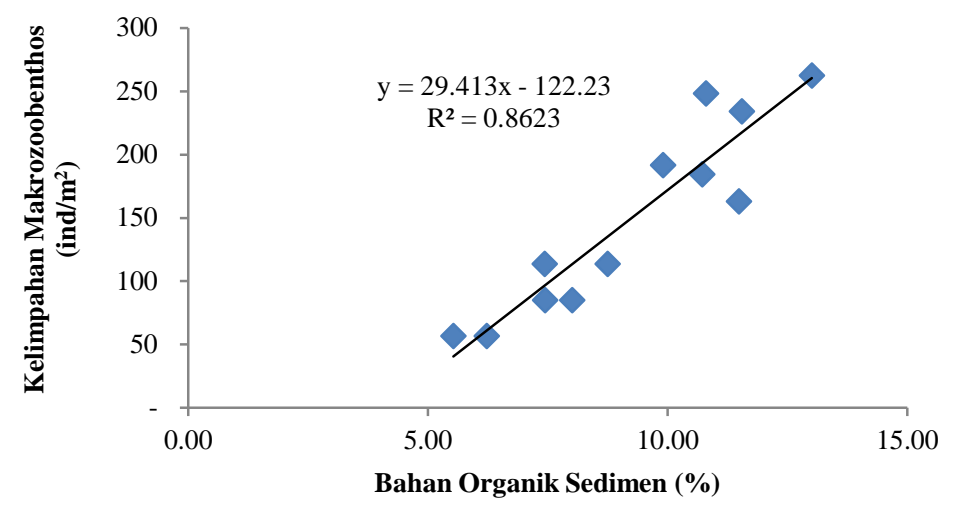

Gambar 2. Hubungan antara bahan organik sedimen dan kelimpahan makrozoobenthos

\section{Hubungan antara tekstur sedimen dan bahan organik sedimen}

a. Hubungan fraksi pasir (sand) dengan kandungan bahan organik sedimen

Berdasarkan hasil uji korelasi regresi, Nilai $\mathrm{R}^{2}$ yang didapatkan diartikan bahwa 79,3\% besarnya kandungan bahan organik sedimen dipengaruhi oleh fraksi pasir (sand), namun 20,7\% sisanya dipengaruhi oleh fraksi lain. Nilai $\mathrm{r}$ sebesar-0,891. Nilai ini menunjukkan bahwa hubungan antara kedua variabel kuat. Hal ini dibuktikan oleh nilai Sig. F sebesar 0,00. Nilai Sig. f lebih kecil dari 0,05. Hal ini menunjukkan adanya pengaruh positif nyata antara fraksi pasir (sand) dengan kandungan bahan organik sedimen. Namun nilai koefesien korelasi negatif, artinya terjadi hubungan berlawanan antara fraksi pasir dan kandungan bahan organik sedimen. semakin besar persentase fraksi pasir, maka semakin kecil kandungan bahan organiknya. Sebaliknya, semakin kecil persentase fraksi pasir, maka semakin besar kandungan bahan organik sedimen. Hal ini sesuai dengan pernyataan Rafni (2004) dalam Hawari et al.,(2014), yang menyatakan bahwa tekstur sedimen berpasir cenderung tidak mengikat begitu banyak bahan organik karena teksturnya yang kasar dan bersifat terpisah-pisahBerikut disajikan grafik persamaan hubungan antara tekstur sedimen, khususnya fraksi pasir (sand) dengan kandungan bahan organik sedimen pada Gambar 3.

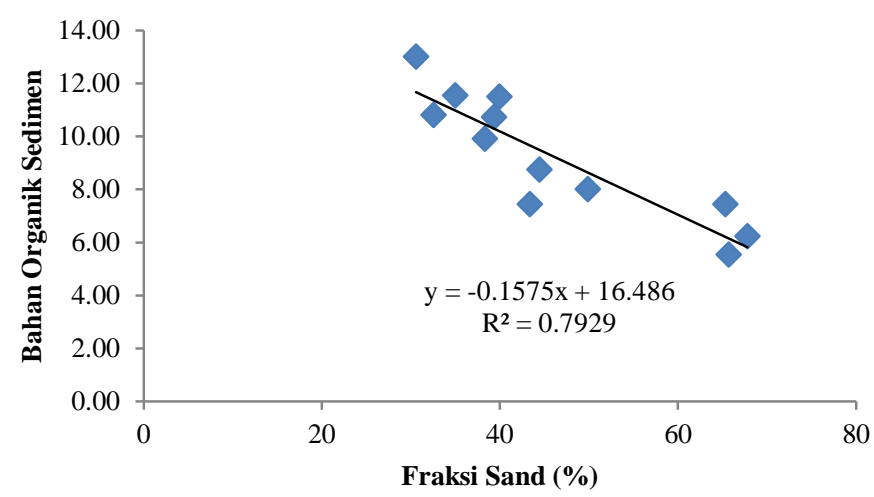

Gambar 3. Hubungan fraksi pasir (sand) dengan bahan organik sedimen.

b. Hubungan fraksi lumpur (silt) dengan kandungan bahan organik sedimen

Berdasarkan hasil uji korelasi regresi Nilai $\mathrm{R}^{2}$ menunjukkan bahwa sebesar 6,21\% fraksi lumpur mempengaruhi kandungan bahan organik sedimen, sedangkan 93,79\% dipengaruhi oleh fraksi lain. Nilai koefesien korelasi dari kedua variabel tersebut adalah sebesar 0,250. Nilai tersebut menunjukkan bahwa hubungan antara fraksi lumpur dengan kandungan bahan organik sedimen adalah rendah. Hubungan tersebut dibuktikan oleh nilai Sig. $\mathrm{f}$ sebesar 0,434. Nilai significance $F$ lebih besar dari 0,05. Hal ini menunjukkan bahwa tidak adanya pengaruh antara fraksi lempung dengan kandungan bahan organik sedimen. Hal ini dikarenakan fraksi lumpur yang didapatkan memiliki persentase kecil. Pernyataan tersebut sangat tidak sesuai dengan Kinasih et al (2015), yang menyatakan bahwa pada umumnya jenis sedimen lumpur lebih kaya akan unsur hara daripada sedimen pasir.Berikut disajikan grafik persamaan hubungan antara tekstur sedimen, khususnya fraksi lumpur (silt) dengan kandungan bahan organik sedimen pada Gambar 4. 


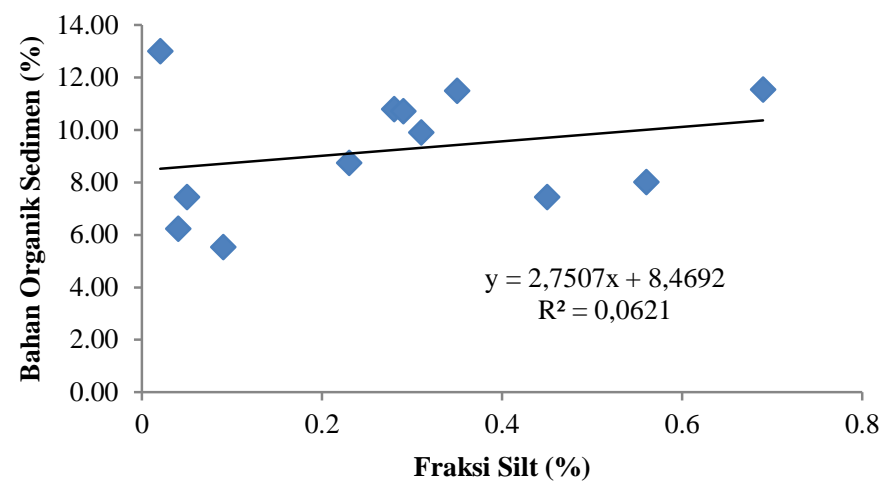

Gambar 4. Hubungan fraksi lumpur (silt) dengan bahan organik sedimen.

c. Hubungan fraksi liat (clay) dengan kelimpahan bahan organik sedimen

Berdasarkan hasil uji korelasi regresi Nilai $\mathrm{R}^{2}$ menunjukkan bahwa sebesar $79,7 \%$ fraksi liat (clay) mempengaruhi besarnya kandungan bahan organik sedimen. Sedangkan 20,3\% dipengaruhi fraksi lain. Nilai koefesien korelasi dari kedua variabel tersebut adalah sebesar 0,893. Nilai tersebut menunjukkan bahwa hubungan antara fraksi liat (clay) dengan kandungan bahan organik sedimen adalah kuat. Hal ini dibuktikan oleh nilai Sig. F sebesar 0,00. Nilai Sig. f lebih kecil dari 0,05. Hal ini menunjukkan adanya pengaruh positif nyata antara fraksi liat (clay) dengan kelimpahan bahan organik sedimen. Hal ini sesuai dengan pernyataan Supriyadi (2008) dalam Putri et al., (2016) yang menyatakan bahwa bahan organik cenderung meningkat dengan meningkatnya kandungan liat.berikut disajikan grafik persamaan hubungan antara tekstur sedimen, khususnya fraksi liat (clay) dengan kandungan bahan organik sedimen pada Gambar 5.

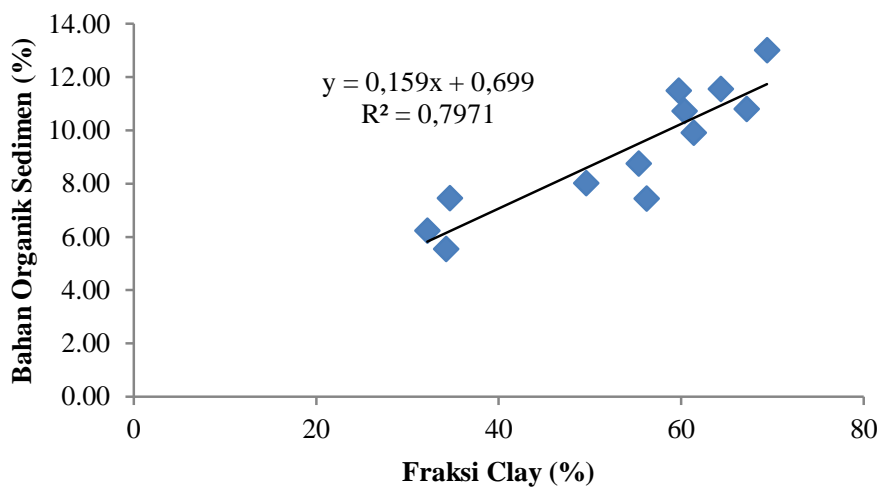

Gambar 5. Hubungan fraksi liat (clay) dengan bahan organik sedimen.

\section{Hubungan antara tekstur sedimen dengan kelimpahan makrozoobenthos}

a. Hubungan fraksi pasir (sand) dengan kelimpahan makrozoobenthos

Berdasarkan hasil uji korelasi regresi Berikut disajikan grafik persamaan hubungan antara fraksi pasir (sand) dengan kelimpahan makrozoobenthos dapat dilihat pada Gambar 6.

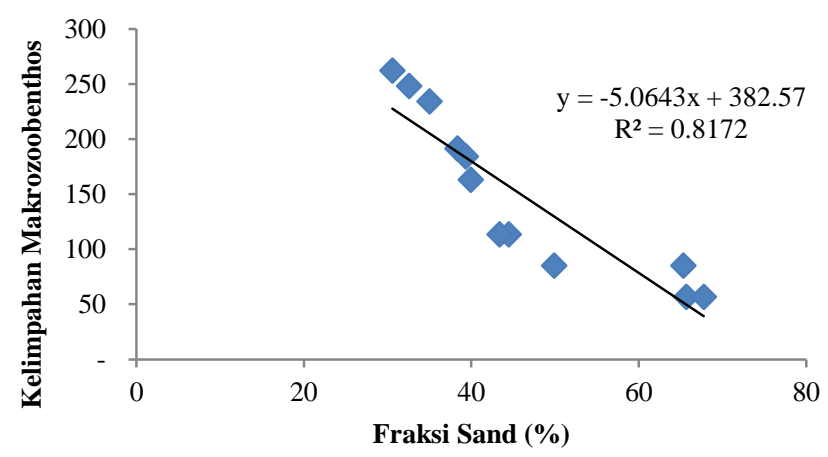

Gambar 6. Hubungan fraksi pasir (sand) dengan kelimpahan makrozoobenthos 
Nilai $\mathrm{R}^{2}$ sebesar 0,8172 . Koefesien determinasi $\left(\mathrm{R}^{2}\right)$ ini menunjukkan bahwa sebesar $81,7 \%$ fraksi pasir mempengaruhi kelimpahan makrozoobenthos di sungai, sedangkan 18,3\% lainnya dipengaruhi oleh fraksi dan faktor lain.Nilai koefesien korelasi dari kedua variabel tersebut adalah sebesar -0,903. Nilai koefesien tersebut menunjukkan adanya korelasi kuat antara fraksi pasir (sand) dengan kelimpahan makrozooobenthos. Hal ini dibuktikan oleh nilai $\mathrm{f}$ hitung sebesar 44,223 dengan Sig. F sebesar 0,00. Nilai f hitung lebih besar daripada $f$ tabel $(4,84)$ dan Sig. f lebih kecil dari 0,05 . Hal ini menunjukkan adanya pengaruh positif nyata antara fraksi pasir (sand) dengan kelimpahan makrozoobenthos. Namun nilai korelasi menunjukkan negatif (-) yang berarti bahwa kedua variabel tersebut memiliki hubungan yang berbanding terbalik. Menurut Nybakken (1992) dalam Ulfah et al., (2012) Tipe substrat berpasir kurang baik bagi pertumbuhan organisme perairan karena memiliki pertukaran masa air yang lambat, kadar oksigen yang rendah dan dapat menyebabkan keadaan anosik sehingga proses dekomposisi yang berlangsung di substrat pada keadaan anaerobik dapat mengakibatkan bau serta tercemarnya perairan.

b. Hubungan fraksi lumpur (silt) dengan kelimpahan makrozoobenthos

Berdasarkan hasil uji korelasi regresi diperoleh koefesien determinasi $\left(R^{2}\right)$ sebesar 0,053 . Nilai $R^{2}$ ini menunjukkan bahwa sebesar 5,3\% fraksi lumpur (silt) mempengaruhi kelimpahan makrozoobenthos, sedangkan 94,7\% lainnya dipengaruhi oleh fraksi dan faktor lain. Nilai koefesien korelasi (r) dari kedua variabel tersebut adalah sebesar 0,231. Nilai koefesien tersebut menunjukkan adanya korelasi yang lemah antara fraksi lumpur (silt) dengan kelimpahan makrozooobenthos. Hal ini dibuktikan oleh nilai Sig. F sebesar 0,471. Nilai Sig. f lebih besar dari 0,05. Hal ini menunjukkan bahwa fraksi lumpur (silt) tidak mempengaruhi kelimpahan bahan organik sedimen. Hal ini disebabkan karena jumlah persentase lumpur (silt) sangat kecil dibandingkan fraksi lainnnya. Fraksi lumpur (silt) memiliki sedikit kandungan oksigen. Hanya organisme yang hidup didalamnya dapat beradaptasi pada keadaan tersebut. Hal ini diperkuat oleh Nybakken (1988) dalam Mentari et al (2015) dan Puspitasari (2012) dalam Putri et al., (2016) yang menyatakan bahwa substrat dasar yang berbeda-beda menyebabkan perbedaan fauna atau struktur komunitas makrozoobentos. Substrat berupa lumpur memiliki sedikit kandungan oksigen dibandingkan pasir.Berikut disajikan grafik persamaan hubungan antara fraksi lumpur (silt) dengan kelimpahan makrozoobenthos dapat dilihat pada Gambar 7.

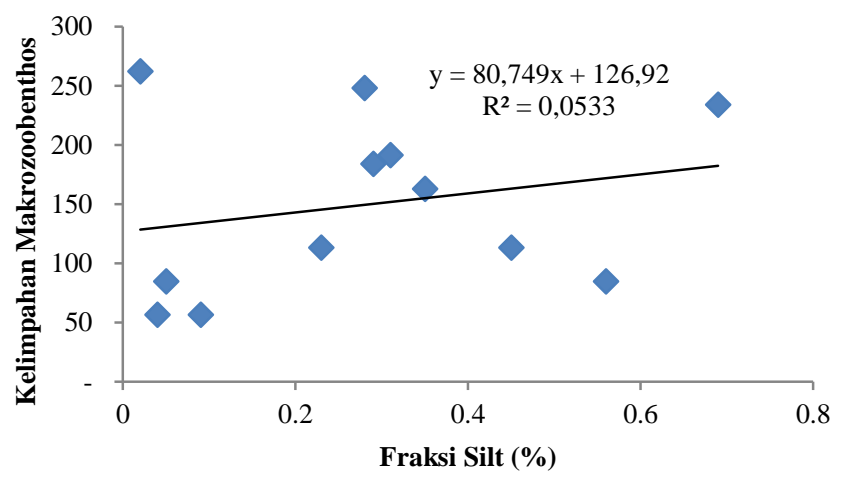

Gambar 7. Hubungan fraksi lumpur (silt) dengan kelimpahan makrozoobenthos.

c. Hubungan fraksi liat (clay) dengan kelimpahan makrozoobenthos

Berdasarkan hasil uji korelasi regresi, diperoleh koefesien determinasi $\left(\mathrm{R}^{2}\right)$ sebesar 0,822 , yang artinya $82,2 \%$ fraksi liat (clay) mempengaruhi kelimpahan makrozoobenthos, sedangkan 17,8\% lainnya dipengaruhi oleh fraksi dan faktor lain. Nilai koefesien korelasi (r) dari kedua variabel tersebut adalah sebesar 0,906. Nilai koefesien tersebut menunjukkan adanya korelasi kuat antara fraksi liat (clay) dengan kelimpahan makrozooobenthos. Fraksi liat memiliki ukuran lebih kecil dibandingkan fraksi lumpur dan pasir. Selain itu kandungan bahan organik sedimen pada fraksi liat (clay) lebih tinggi dibandingkan kandungan bahan organik sedimen pada fraksi lainnya. Hal ini yang menyebabkan makrozoobenthos lebih menyukai habitat yang memiliki sedimen halus (liat). Menurut Ario dan Handoyo (2002) dalam Shalihah et al., (2017), Komposisi jenis gastropoda yang tinggi berkaitan dengan sifat biologis dan ekologis. gastropoda lebih menyukai habitat tanah yang halus dengan kandungan bahan organik yang tinggi. Berikut disajikan grafik persamaan hubungan antara fraksi liat (clay) dengan kelimpahan makrozoobenthos dapat dilihat pada Gambar 8 . 


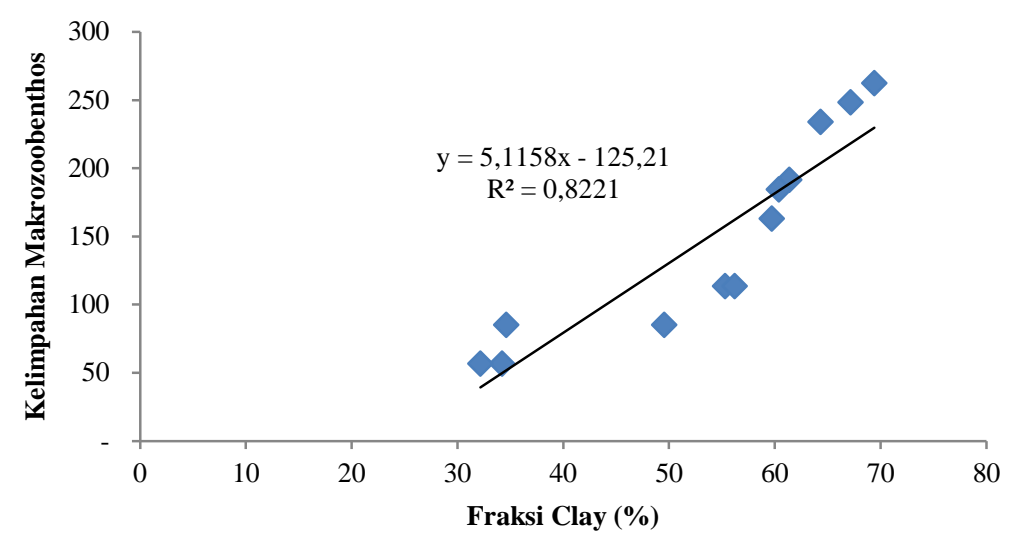

Gambar 8. Hubungan fraksi liat (clay) dengan kelimpahan makrozoobenthos.

\section{Kesimpulan}

Kesimpulan yang diperoleh dari penelitian mengenai Hubungan antara Tekstur Sedimen, kandungan Bahan Organik dan Kelimpahan Makrozoobenthos di Perairan Muara Banjir Kanal Barat, Semarang adalah tekstur sedimen didominasi oleh liat dan pasir. Fraksi liat erat hubungannya dengan kandungan bahan organik sedimen dan makrozoobenthos. Makrozoobenthos lebih menyukai tempat hidup yang memiliki nutrien cukup untuk makanannya.

\section{UCAPAN TERIMA KASIH}

Penulis mengucapkan terima kasih kepada, Ibu Ir. Siti Rudiyanti, M.Si. dan Ibu Nurul Latifah, S.Kel, M.Si. yang telah memberikan saran untuk perbaikan artikel ini.

\section{DAFTAR PUSTAKA}

Buchanan, J.B. 1984. Sediment Analysis. In Home And Mclntryre. Method Of Study Of Marine Bethos. Blackel Scientific Publication, London.

Choirudin, I.R., M.N. Supardjo. dan M.R. Muskananfola. 2014. Studi Hubungan Kandungan Bahan Organik Sedimen dengan Kelimpahan Makrozoobenthos di Muara Sungai Wedung Kabupaten Demak. Journal of Maquares. 3 (3). 168-176.

Fitriana, Y.R. 2005. Keanekaragaman dan Kelimpahan Makrozoobenthos di Hutan Mangrove Hasil Rehabilitasi Taman Hutan Raya Ngurah Rai Bali. Jurnal Biodiversitas. 7 (1) : 55-63.

Hadiputra, M.A. dan A. Damayanti. 2013. Kajian Potensi Makrozoobenthos sebagai Bioindikator Pencemaran Logam Berat Tembaga $(\mathrm{Cu})$ di Kawasan Ekosistem Mangrove Wonorejo Pantai Timur Surabaya. dalam : Prosiding Seminar Nasional Manajemen Teknologi XVIII tanggal 27 Juli 2013 di Surabaya. Institut Teknologi Sepuluh Nopember, Surabaya, 1-8 hlm.

Hawari. A., B. Amin dan Efriyeldi. 2013. Hubungan Antara Bahan Organik Sedimen dengan Kelimpahan Makrozoobenthos di Perairan Pantai Pandan Provinsi Sumatera Utara. Fakultas Perikanan dan Ilmu kelautan. Universitas Riau, $11 \mathrm{hlm}$.

Kinasih, A.R.N., P.W. Purnomo. dan Ruswahyuni. 2015. Analisis Hubungan Tekstur Sedimen dengan Bahan Organik, Logam Berat $(\mathrm{Pb}$ dan $\mathrm{Cd})$ dan Makrozoobenthos di Sungai Betahwalang, Demak. Diponegoro Journal of Maquares. 4 (3) : 99-107.

Mentari, L., Ruswahyuni, dan M.R. Muskananfola. 2015. Distribusi Kelimpahan Makrozoobenthos dan Kandungan Bahan Organik serta Tekstur Sedimen pada Muara Sungai Wakak, Kabupaten Kendal. Diponegoro Journal of Maquares. 4 (4) : 19-23.

Mushthofa, A., M.R. Muskananfola. dan S. Rudiyanti., 2014. Analisis Struktur Komunitas Makrozoobenthos sebagai Bioindikator Kualitas Perairan Sungai Wedung, Kabupaten Demak.Journal of Maquares., 3 (1) : 81-88.

Noortiningsih., I.S. Jalip dan S. Handayani. 2008. Keanekaragaman Makrozoobenthos, Meiofauna dan Foraminifera di Pantai Pasir Putih Barat dan Muara Sungai Cikamal Pangandaran, Jawa Barat. Vis Vitalis. Fakultas Biologi Universitas Nasional, Jakarta, 1 (1) : 34-42.

Putri, A.M.S., Suryanti dan N. Widyorini. 2016. Hubungan Tekstur Sedimen dengan Kandungan Bahan Organik dan Kelimpahan Makrozoobenthos di Muara Sungai Banjir Kanal Timur Semarang. Jurnal Saintek Perikanan. 12 (1) :75-80. 
Ridwan, M., R. Fathoni., I. Fatihah dan D.A. Pangestu. 2016. Struktur Komunitas Makrozoobenthos di Empat Muara Sungai Cagar Alam Pulau Dua, Serang, Banten. Jurnal Biologi. Fakultas Sains dan Teknologi Universitas Islam Negeri (UIN) Syarif Hidayatullah Jakarta, 9 (1) : 57-65.

Shalihah, H.N., P.W. Purnomo dan N. Widyorini. 2017. Keanekaragaman Moluska Berdasarkan Tekstur Sedimen dan Kadar Bahan Organik pada Muara Sungai Betahwalang Kabupaten Demak. Jurnal Saintek Perikanan. 13 (1) : 58-64.

Suryani dan Hendyadi. 2015. Metode Riset Kuantitatif Teori dan Aplikasi pada Penelitian Bidang Manajemen dan Ekonomi Islam. Prenadamedia Group, Jakarta, $326 \mathrm{hlm}$.

Ulfah, Y., Widianingsih, dan M. Zainuri. 2012. Struktur Komunitas Makrozoobenthos di Perairan Wilayah Morosari Desa Bedono Kecamatan Sayung Demak. Journal of Marine Research. 1 (2): 188-196. 